Regionalism and Globalism in Southeast Asia 
Also by Eero Palmujoki

VIETNAM AND THE WORLD: Marxist-Leninist Doctrine and the Changes in International Relations 


\section{Regionalism and Globalism in Southeast Asia}

Eero Palmujoki

Senior Fellow

Tampere Peace Research Institute

University of Tampere

Finland

palgrave 


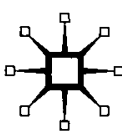

(C) Eero Palmujoki 2001

Softcover reprint of the hardcover 1st edition 2001 978-0-333-73477-3

All rights reserved. No reproduction, copy or transmission of this publication may be made without written permission.

No paragraph of this publication may be reproduced, copied or transmitted save with written permission or in accordance with the provisions of the Copyright, Designs and Patents Act 1988, or under the terms of any licence permitting limited copying issued by the Copyright Licensing Agency, 90 Tottenham Court Road, London W1T 4LP.

Any person who does any unauthorised act in relation to this publication may be liable to criminal prosecution and civil claims for damages.

The author has asserted his right to be identified as the author of this work in accordance with the Copyright, Designs and Patents Act 1988.

First published 2001 by

PALGRAVE

Houndmills, Basingstoke, Hampshire RG21 6XS and 175 Fifth Avenue, New York, N. Y. 10010

Companies and representatives throughout the world

PALGRAVE is the new global academic imprint of St. Martin's Press LLC Scholarly and Reference Division and Palgrave Publishers Ltd (formerly Macmillan Press Ltd).

ISBN 978-1-349-40808-5

ISBN 978-0-230-50469-1 (eBook)

DOI $10.1057 / 9780230504691$

This book is printed on paper suitable for recycling and made from fully managed and sustained forest sources.

A catalogue record for this book is available from the British Library.

Library of Congress Cataloging-in-Publication Data Palmujoki, Eero, 1958-

Regionalism and globalism in Southeast Asia / Palmujoki, Eero. p. $\mathrm{cm}$.

Includes bibliographical references and index.

1. Asia, Southeastern-Politics and government-19452. Asia, Southeastern-Economic conditions. 3. Regionalism-Asia, Southeastern. I. Title.

JQ750.A58 P35 2001

$327^{\prime} .0959-\mathrm{dc} 21$

2001034817

$\begin{array}{llllllllll}10 & 9 & 8 & 7 & 6 & 5 & 4 & 3 & 2 & 1\end{array}$

$\begin{array}{llllllllll}10 & 09 & 08 & 07 & 06 & 05 & 04 & 03 & 02 & 01\end{array}$ 


\section{Contents}

Acknowledgements vii

Abbreviations $\quad$ ix

1 Introduction: Analyzing Southeast Asian

Regionalist Efforts $\quad 1$

New Regionalism and the Regionalist Debate 1

Theoretical Patterns of Southeast Asian Regionalist Discourse 3

Regionalist Discourse in Political Context: A Historical

Perspective

Academic and Political Discourse on Southeast Asian

Regionalism: Some Conclusions

PART I THE PRINCIPLES OF ASEAN'S INTERSTATE RELATIONS IN PRACTICE

2 Widening or Deepening Regional Cooperation?

Taking the Political Approach: ASEAN and the New Members 38

The Rationality of Intra-ASEAN Economic Cooperation 50

3 Regionalism and Security in Southeast Asia 62

The Concept of Security in ASEAN 63

Extending the ASEAN Conflict Management Mechanism 67

Realists, the ARF and China in the Southeast Asian Power

Equation

PART II REGIONAL RESPONSES TO GLOBAL CHALLENGES

4 ASEAN in the Asia-Pacific Context 81

ASEAN and East Asia: The EAEC and Beyond 82

Characterizing ASEAN's Role in the Asia-Pacific Context 88

APEC and ASEAN $\quad 92$ 
5 ASEAN and the EU: Politico-ideological Conflict and Economic Necessities

Introduction

Southeast Asian and European Institutionalist Ideas in

Agenda-Setting

The EU's Asia Strategy and ASEAN 101

ASEAN's Regionalism and the EU

From the EU-ASEAN Dialogue to the Asia-Europe Meeting

PART III SOUTHEAST ASIAN REGIONALISM AFTER THE ASIAN ECONOMIC CRISIS

6 The Asian Economic Crisis, the Southeast Asian Countries and ASEAN

The East Asian Miracle and Southeast Asian Regionalism

From Currency Crisis to Political Crises

7 Global Governance and Regionalist Solutions

Economic Regimes and the Southeast Asian Countries

Southeast Asian Political Crises, Global Interventions and Regional Approaches

8 Southeast Asian Regionalist Trends in the Beginning of the New Millennium

The Legacy of the 1990s

Post-Crisis Institutionalism and Functionalism

ASEAN and East Asian Integration

ASEAN and the Environment: from Trade Issues to

Sustainable Development

ASEAN and the NGOs: Regionalism from Below

9 Conclusion: Southeast Asian Regionalism: Old or New? 


\section{Acknowledgements}

This study is an outcome of several research projects carried out at the Department of Political Science and International Relations and at the Tampere Peace Research Center (TAPRI) within the University of Tampere. The main sources of funding have been three research projects sponsored by the Academy of Finland, namely: "Regionalism and globalism in Southeast Asia", "Regionalism, globalism and the development of the inter-state system in Southeast Asia" and "The Regional and local policy impacts of the global environmental and climate regimes". The initiative for the research originated in 1996 from the Finnish Ministry for Foreign Affairs, which made it possible to start the project and supported it during the entire research period. A senior fellowship at TAPRI enabled me to finalise this book.

Owing to these three projects, several persons have inspired the ideas for my study. Inevitably, the book includes thoughts and views of my colleagues in our Southeast Asia project: Annamari Antikainen-Kokko, Janne Jokinen, Anisa Doty and Teemu Tuominen. Although the project was sometimes difficult to administer, the effort as such was stimulating, operating among three universities (Universities of Tampere, Turku and Abo Akademi University) and three departments. In addition, with the particular support of the Foreign Ministry, it differed from more conventional academic research projects. Indeed, the interests and support of the Foreign Ministry staff for our network were very important. Hannu Mäntyvaara and Mikko Jokela flexibly connected the need for policy information to academic interests and Paula Parviainen and Markku Heiskanen, among many other officials at the Foreign Ministry, gave an important practical policy perspective on Southeast Asian affairs.

The research project included three research trips to Southeast Asia. I am indebted to several colleagues and friends in Malaysia, the Philippines, Singapore and Thailand for their hospitality and help. Here I would also like to thank: Miriam Coronel Ferrer, Derek da Cunha, Jalil Miswardi and Hong Chee, Suthiphand Chirathivat, Yupin Chancharoensin and Yeo Lay Hwee. I would particularly like to mention the help of librarians at the Institute of Southeast Asian Studies in Singapore, at the library of Chulalongkorn University in Bangkok and at the Institute of Strategic and International Studies in Kuala Lumpur. 
I have also received important practical help in my research. Riitta Lehtimäki at the Department of Political Science and International Relations has patiently administrated my projects and Erja Yläjärvi collected material on the Asian economic crisis. Joan Lofgren, Virginia Mattila and Tina Parke-Sutherland did a lot of work in editing my English. Finally, Marita Alanko professionally prepared the manuscript for the publisher.

To carry out an academic research project is often a stressful job of combining intellectual intentions and financial realities. I am thankful to my wife, Sirkku, for understanding this insecurity. I am also very much obliged to my colleagues at the Department of Political Science for their support: Pertti Lappalainen, Juha Holma, Tarja Seppä, Tapani Turkka and Pekka Virtanen, from whom, I am afraid, I have got more than I have given.

A part of the material presented in this book has appeared in other publications. The earlier version of the first chapter, "Integration and Fragmentation in Southeast Asian Regionalist Discourse", was published previously in a Special Issue of the Journal of the Finnish Anthropological Society, Volume 25 No. 2 (June 2000), pp. 76-88 and a shorter version of Chapter Five has appeared as "EU-ASEAN Relations: Reconciling Two Different Agendas" in Contemporary Southeast Asia, Volume 19, No. 3, December 1997,pp. 269-285. Reproduced here with the kind permission of the publisher, Institute of Southeast Asian Studies, Singapore. 


\section{Abbreviations}

$A C U$

ADB

ADS

AEM

AFMM

AFTA

AIA

AIPO

AMM

APEC

ARF

ASCU

ASEAN

ASEAN-ISIS

ASEM

ASEP

ASFOM

ASTSU

CBM

CDC

CEER

CEPHCP

CEPT

CER

CFSP

CLOB

CSCA

CSCAP

CSCE

EAEC

EAEG

EC

EEC
ASEAN Currency Unit

Asian Development Bank

ASEAN Document Series

ASEAN Economic Ministers (meeting)

ASEAN Finance Minister's Meeting

ASEAN Free Trade Area

ASEAN Investment Area

ASEAN Inter-parliamentary Organization

ASEAN Ministerial Meeting

Asia-Pacific Economic Cooperation

ASEAN Regional Forum

ASEAN Surveillance Coordinating Unit

Association of Southeast Asian Nations

ASEAN Institutes of Strategic and International Studies

Asia-Europe Meeting

ASEAN Subregional Environment Program

ASEAN Senior Finance Official's Meeting

ASEAN Surveillance Technical Support Unit

Confidence-building measure

Committee on Development and Cooperation

(the EU Parliament)

Committee on External Economic Relations

(the EU Parliament)

Committee on the Environment, Public Health and

Consumer Protection (the EU Parliament)

Common Effective Preferential Tariff

Closer Economic Relations

(between Australia and New Zealand)

(European Union's) common foreign and security policy

Central Limited Order Book

Conference on Security Cooperation in Asia

Council for Security Cooperation in the Asia Pacific

Conference on Security and Cooperation in Europe

East Asian Economic Caucus

East Asian Economic Grouping

European Community

European Economic Community 


\begin{tabular}{|c|c|}
\hline EPC & European Political Cooperation \\
\hline EU & European Union \\
\hline FAB & $\begin{array}{l}\text { Foreign Affairs Bulletin } \\
\text { (the Thai Ministry of Foreign Affairs) }\end{array}$ \\
\hline FAC & Foreign Affairs Committee (the EU Parliament) \\
\hline FAM & $\begin{array}{l}\text { Foreign Affairs Malaysia } \\
\text { (the Malaysian Ministry of Foreign Affairs) }\end{array}$ \\
\hline FAN & $\begin{array}{l}\text { Foreign Affairs Newsletter } \\
\text { (the Thai Ministry of Foreign Affairs) }\end{array}$ \\
\hline FDI & Foreign Direct Investments \\
\hline FEER & Far Eastern Economic Review \\
\hline FSC & Forest Stewardship Council \\
\hline FTA & Free trade area \\
\hline GATT & General Agreement on Tariffs and Trade \\
\hline GDP & Gross domestic production \\
\hline HPEA & High performing Asian economies \\
\hline HS & Harmonized Commodity Description and Coding System \\
\hline IAI & Initiative for ASEAN Integration \\
\hline IMF & International Monetary Fund \\
\hline IPE & International political economy \\
\hline ISO & International Standard Organization \\
\hline IT & Information technology \\
\hline ITO & International Trade Organization \\
\hline ITTO & International Timber Trade Organization \\
\hline KLSE & Kuala Lumpur Stock Exchange \\
\hline MAI & Multilateral Agreement on Investments \\
\hline MERCOSUR & Mercado Común del Sur \\
\hline $\mathrm{MNC}$ & Multinational company \\
\hline NAFTA & North American Free Trade Agreement \\
\hline NAM & Non-Aligned Movement \\
\hline NEP & New Economic Policy \\
\hline NGO & Non-governmental organization \\
\hline NIC & Newly industrialized country (in Asia) \\
\hline NTB & Non-tariff barrier \\
\hline OECD & $\begin{array}{l}\text { Organization for Economic Cooperation and } \\
\text { Development }\end{array}$ \\
\hline PAP & People's Action Party \\
\hline PBEC & Pacific Basin Economic Council \\
\hline PECC & Pacific Economic Co-operational Council \\
\hline PIWP & $\begin{array}{l}\text { ASEAN Customs Policy Implementation and Work } \\
\text { Programme }\end{array}$ \\
\hline
\end{tabular}




$\begin{array}{ll}\text { PMC } & \text { (ASEAN) Post-Ministerial Conference } \\ \text { PRC } & \text { People's Republic of China } \\ \text { PTA } & \text { Preferential trade arrangement } \\ \text { RHAP } & \text { Regional Haze Action Plan } \\ \text { SAL } & \text { Structural Adjusted Loans } \\ \text { SEOM } & \text { (ASEAN) Senior Officials Meeting } \\ \text { SLORC } & \text { State Law and Order Restoration Council } \\ \text { STABEX } & \text { Stabilization of export earning scheme } \\ \text { TAC } & \text { Treaty of Amity and Cooperation in Southeast Asia } \\ \text { UMNO } & \text { United Malays National Organization } \\ \text { UNEP } & \text { United Nations Environment Program } \\ \text { UNTAET } & \text { United Nations Transitional Administration in } \\ & \text { East Timor } \\ \text { WTO } & \text { World Trade Organization } \\ \text { ZOPFAN } & \text { Zone of Peace, Freedom and Neutrality }\end{array}$

